RAZING A BIG STACK WITH DYNAMITE. BY GEORGE D. MYTCHELL

How to safely and expeditiously bring to earth a big brick smokestack 153 feet high, located facing the principal thoroughfare of the national capital, with many buildings dangerously near, was the problem that recently presented itself to the District of Colum. bia authorities.

About eight years ago the Capital Traction Company

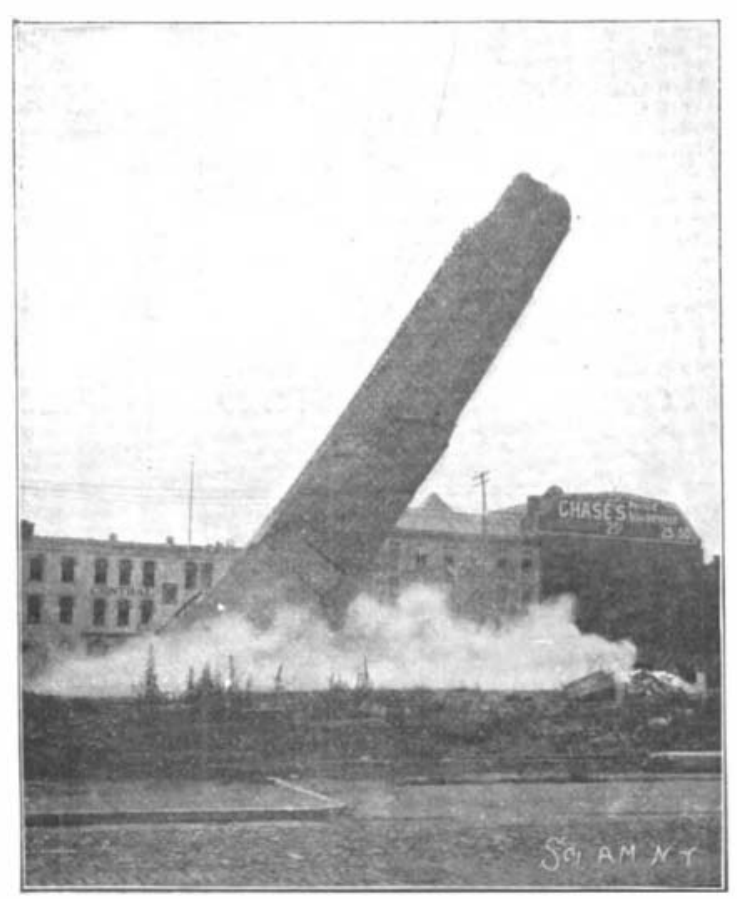

RAZING A BIG STACK WITH DYNAMITE AT WASHINGTON, D. C.

built a five-story cable power house in Washington occupying the entire half-square between $\mathrm{D}$ and $\mathrm{E}$ and Thirteen-and-a-half and Fourteenth Streets, and facing Pennsylvania Avenue, near the National Theater, Wiilard's Hotel and other landmarks. The building was of quasi-fireproof construction, with timber girders, wood floors, partitions made of Southern pine covere with thin steel sheathing. It hurned about five years ago, and the ruins were roughly cleared away after the fire, but the heavy engine foundations and the tall stack were left in place, and the site was abandoned by the company. Congress at the last session provided for the purchase of the ground as a location for a fine new municipal building for the District of Columbia. It was decided to clear off and level the site in time for it to be used in connection with the national encampment of the Grand Army of the Republic in October.

There was considerable stonework in the founda tions, there were upward of 250,000 brick in the stack and more or less loose material was scattered about on the ground. It was thought, on general principles, that the contractor who took the job of clearing the sit should be willing to pay a liberal sum for the privilege in consideration of
of buildings was situated only ninety feet away from the stack, just
across D Street, across D Street, and as there were other buildings on the other sides of the square, at distances of 200 to 400 feet, the authorities place se vere restrictions on the methods to-be employe in razin the stack; and th result was that what was at first considered to be ar e as y proposition went begging for takers There were a number of contractors who were willing to undertake the work on their own cond

tions, but finally the contract was placed with James L. Carrick, the only serious bidder, who had bid the modest sum of $\$ 60$ for the privilege. The contract for demolishing the stack was sublet to Henry O. Brown. The stack was fifteen feet square at the base, with walls nearly three feet thick tapering to a thicknes of thirteen inches at the top. The construction wa carried square to a point about forty feet from the ground, where the third floor of the building had come, and from there it was octagonal, the interior being lined for about two-thirds of the way up with firebrick.

The district authorities had stipulated that the stack must be lowere by hand sixty feet before any explo sives could be used on it. This was the main condition which hampered the undertaking, and it took nearly two weeks to take off the prescribed sixty feet, as the last thirty feet was an 18-inch wall.

In preparation for the final stroke the northeast and northwest corners of the base of the stack were undermined. Holes were drilled in the intervening sections of wall on the north side, and a series of halfpound sticks of dynamite were inserted. At the appointed signal the battery was thrown in and there was a deafening roar. For an instant the stack seemed poised bodily in the air, and then it began to fall directly across the vacant site to the north, as planned. It was not blown over by the explosion; the dynamite was used simply to blow out the supporting leg on the undermined side. The stack did not go over absolutely as a whole. It broke in several places, toward the middle, as may be seen in the snapshot illustration of the fall. That is to say, the lower part of the stack was the first to begin to fall, or give way, and the motion was not communicate instantaneously to the upper portion.

The débris was confined within a much smaller space than might have been supposed. Not a particle of material was blown away with any force by the blast, and the farthest brick fell only about 120 feet from the bottom of the stack. The bricks were de posite in a fairly regular we ge-shape pile, comparatively few of them being broken. Nearly all those in the upper two-thirds of the stack were separate from one another, but the thick lower walls were left mainly in masses, up to five feet in length, the charge not being heavy enough to disintegrate them. Thanks to the careful precautions taken, there was no damage tone to neighboring properties, and the work was a done to neighboring properties,
complete success throughout.

\section{THE RAMESES COLOSSUS}

$$
\text { RA ALBERTA FIELD. }
$$

Among the many colossi with which Rameses II adorned the different temples throughout his kingdom there is no more characteristic representation of thi ruighty ruler of the desert, according to our own ideal forme from our historic knowledge of him, than the mighty colossus of Memphis, which now belongs to the British nation. Raise from its Nile bed within the last few years, where it has lain face downward for centuries, reposing calmly beneath the waters of the sacred river save at the dry season, when it became visible until the inundation again buried it it now rests high and dry above all dangers of high water, rests high and dry above all dangers of high water, on heavy pedestals of stonework. Originally this figure Temple of Pthah, the ancient god of Universal Life or Artisan of the World, as he is called by Jamblichus, which temple Rameses II. further enriched with th colossi. The companion figure, however, which supported the opposite portal is absent, and its representation is shrouded in mystery, the mute but impressive lips of the recumbent statue holding firmly the secre thereof. In fact, there is but little evidence remaining the caryatid colossi of the temples, the fallen statue of Bedreshayne, and the crowning glory of the magnificent colossus of the Ramesseum. The same boyish grace of features is followe in maturing lines, developing into the completed physiognomy of the older representations. The illustration fails to thrill one with an appreciation of the magnitude of this colossus, the estimated height of which is about fifty feet the headcap or helmet alone measuring about nine feet,

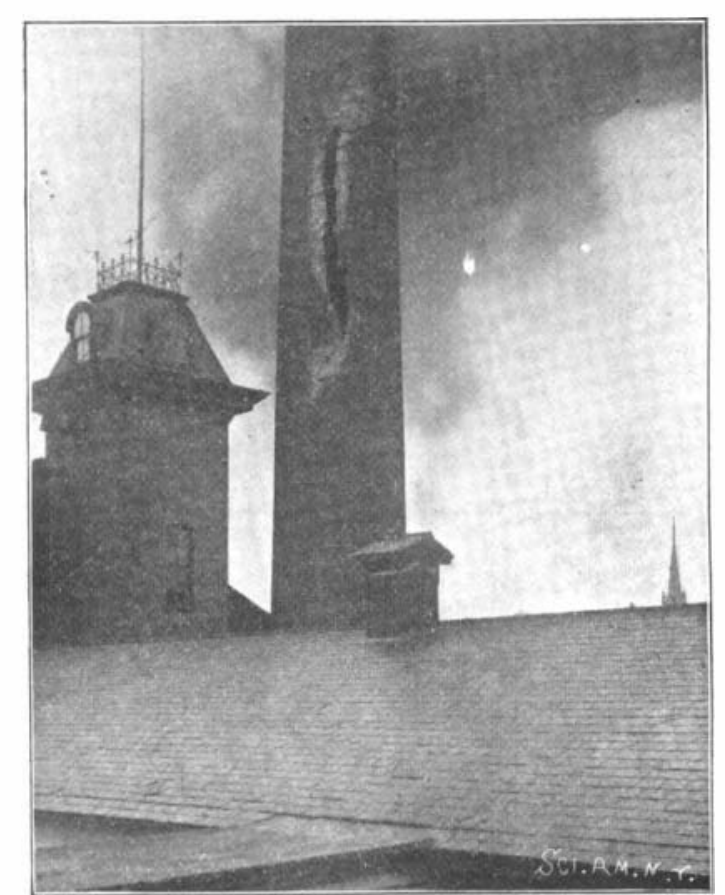

EFFECT OF LIGHTNING ON A TALL FACTORY CHIMNEY.

and which is standing on a pedestal at the left of the illustration. The symmetry of the right arm is notice. able, as is also the firm grasp of the hand, which is characteristic of power.

\section{CURIOUS EFFECT OF LIGHTNIAG ON A BRICK CHIMNEY.}

At about half-past two o'clock on the morning of July 18, during one of the most terrific thunderstorms that ever visite the vicinity, the large brick stack of the Jamestown Worsted Mills was struck by lightning. This stack is 165 feet high and is capped by a heavy cast iron plate, but is unprotected by a lightning rod. A large hole was torn in the chimney near the top, and the outer courses of brick were stripped and cracked for a distance of nearly half-way down. The bolt then jumped to the other side of the chimney, and there tore out a long vertical S-shaped gash, scattering the bricks in each case with a violence which broke them into fragments, and flung the fragments to a distance of two or three hundred feet, breaking windows and roofing slates in every direction. The further course of the lightning is not traceable.

The force which tore the brick out seems only com parable to the action of an explosive; yet the walls

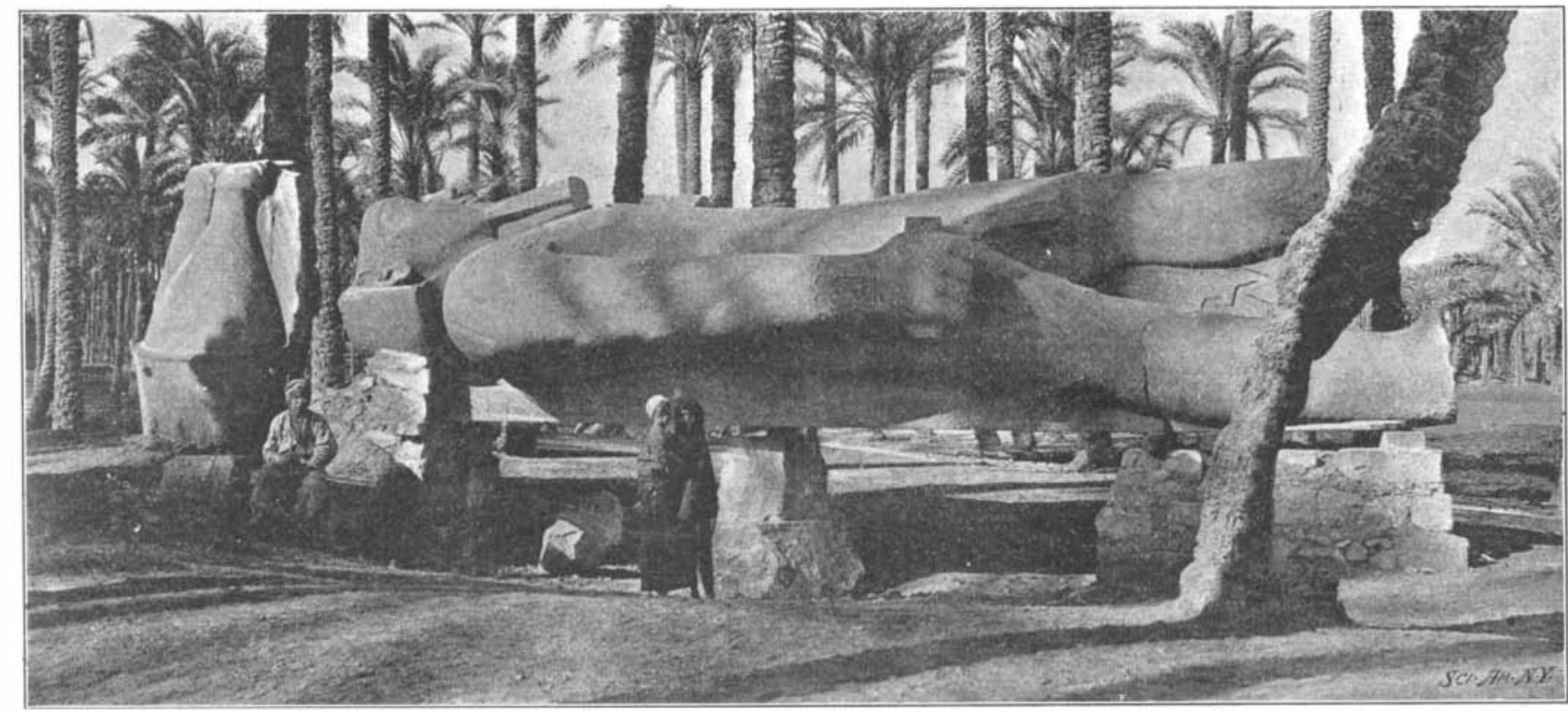

THE COLOSSAL STATUE OF RAMESES.

of this temple, save great mounds of decaying and rumbling granite and conglomerate.

There is a marked facial resemblance among all of the stone representations of Rameses II. which is curiously noticeable on account of the difference of perio and place of construction. The universal likeness predominates among the numerous bass-relief and colossi; from the youthful outline at Bayt-el-Welly to the older representations at Abydos, and so on to Flushing, New York. next the gashes were not broken or strained except for a short distance along the west side. The factory was starte at the usual time next morning. tion proved the stability of the chim ney to be unaffect ed. A fine octag onal scaffold was erected, exactly conforming to the ney, and the holes were all brick in leaving the stro ture in practically as good condition as ever.

Th e Municipa Art Society of New York recently eld a competition for the best design of lamp post for use on the "isles of safety" to be provided on the more crowded of the New York streets at the junctions, as an aid to persons desiring to cross. The prizes were awarded as follows: First prize, $\$ 500$, to Victor A. Ciani, New York; second prize, $\$ 100$, to Henrik Wallin, New York; third prize, $\$ 50$, to Wilkenson \& Megonigle, New York; honorable mention, Edith W. Borroughs, 